\title{
KIF11 wt Allele
}

National Cancer Institute

\section{Source}

National Cancer Institute. KIF11 wt Allele. NCI Thesaurus. Code C79079.

Human KIF11 wild-type allele is located in the vicinity of $10 \mathrm{q} 24.1$ and is approximately 62

$\mathrm{kb}$ in length. This allele, which encodes kinesin-like protein KIF11, is involved in the regulation of spindle dynamics during mitosis. 